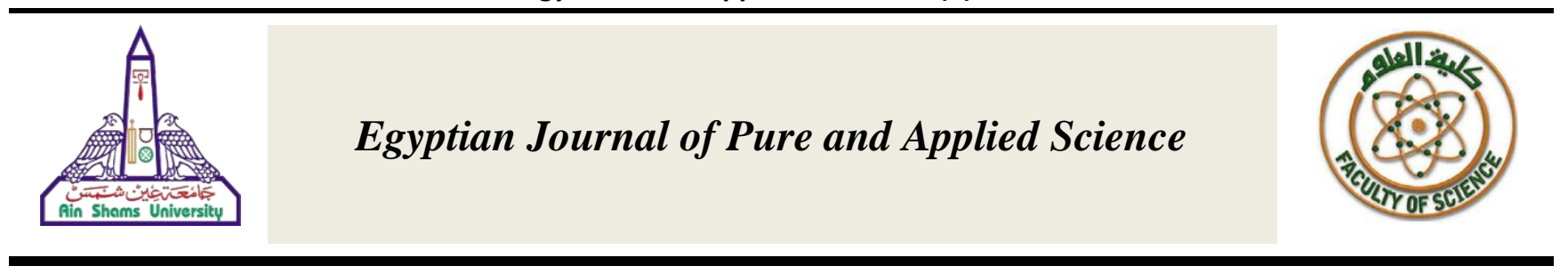

\title{
Dynamics of PAH-Degrading Bacteria and Corresponding Marker Genes in Different Petroleum Hydrocarbon-Contaminated Soils in Almadina Almunawarah, KSA
}

\author{
W. S. El-Sayed ${ }^{1}$, A. A. Al-Fraidi², N. S. Al-Kaff², M. M. Elbadry ${ }^{3}$ \\ ${ }^{1}$ Microbiology Department, Faculty of Science, Ain Shams University, Cairo, Egypt. \\ ${ }^{2}$ Biology Department, Faculty of Science, Taibah University, Almadina Almunawarah, Kingdom of Saudi Arabia. \\ ${ }^{3}$ Agricultural Microbiology Department, Faculty of Agriculture, Fayoum University, Fayoum, Egypt.
}

\section{ARTICLE INFO}

Received 24 August 2021

Accepted 03 November 2021

Keywords

Catabolic genes,

DGGE,

Dioxygenases,

Polycyclic Aromatic Hydrocarbons,

$16 \mathrm{~S}$ rDNA.

\section{Correspondence}

W. S. El-Sayed

\section{E-mail}

waelsamir@sci.asu.edu.eg, waelsme@yahoo.com

\section{ABSTRACT}

Soil contamination with petroleum derivatives, including polycyclic aromatic hydrocarbons (PAHs), is an increasing problem in various parts of the world. Dynamics of bacterial communities were examined in different petroleumcontaminated soils to assess patterns of microbial responses to PAH contamination. Bacterial community fingerprints were determined using denaturing gradient gel electrophoresis (DGGE) of 16S rRNA gene as a molecular marker. Sequence-based identification of dominant DGGE bands in petroleum hydrocarbon-contaminated soils revealed the presence of Pseudomonas sp., $P$. pseudoalcaligenes, $P$. nitroreducens, $P$. toyotomiensis, and uncultured Pseudomonas clones as the dominant bacterial groups. In a laboratory scale microcosm, prolonged incubation of contaminated soils resulted in marked deterioration of bacterial communities. DGGE fingerprints of PAH-amended microcosms indicated the presence of distinct bands corresponding to hydrocarbon-degrading bacteria, such as $P$. mendocina, Cellulosimicrobium sp., Stenotrophomonas sp., and Sphingobacterium sp., which were barely detected in unamended soils. Bacterial community structure in amended soils remained stable even after prolonged incubation up to 6 months. Catabolic genes for upper aromatic hydrocarbon metabolism, such as those encoding naphthalene dioxygenase, toluene dioxygenase (todC1), and Rieske-type proteins of dioxygenases and lower pathway genes encoding catechol 1,2dioxygenase and catechol 2,3-dioxygenase ( $\mathrm{C} 230$ and $x y / E)$ were used as biomarkers for monitoring PAH biodegradation in constructed microcosms. Among all tested primer sets, those for $\mathrm{C} 23 \mathrm{O}$ and naphthalene dioxygenase allowed efficient amplification of extradiol ring cleavage dioxygenase and naphthalene dioxygenase, respectively, from soil samples amended with naphthalene as a model PAH compound. The results indicated the dominance of ring cleavage dioxygenases of the meta pathway and naphthalene dioxygenase in contaminated soils of Almadina Almunawarah, Yanbu city, Saudi Arabia, and their possible use as biomarkers for screening PAH biodegradation in petroleum hydrocarbon-contaminated soils. 


\section{Introduction}

Polycyclic aromatic hydrocarbons (PAHs) are hydrophobic aromatic compounds characterized by two or more fused phenyl rings in different arrangements. PAHs are produced from petroleum refining, waste incineration and coal gasification. Because of their ubiquitous nature, PAHs are found in soil ${ }^{[1]}$, air ${ }^{[2]}$, and water ${ }^{[3]}$. They have been discovered in tobacco smoke, motor engine emissions, and in foods such as smoked fish and meats, and leafy vegetables ${ }^{[4]}$. They are considered potentially carcinogenic and mutagenic to humans if they enter the food chain and therefore being listed as priority pollutants by the United States Environmental Protection Agency ${ }^{[5]}$.

Biodegradation of PAH-contaminated sites is dependent on either the presence of indigenous PAHdegrading bacteria ${ }^{[6,7]}$ or the introduction of selected microorganisms with potential catabolic properties ${ }^{[8]}$. Studying the in-situ response of microorganisms to various contaminants has led to the identification of specific microbial communities with potential uses in biological treatment protocols ${ }^{[9-11]}$.

PAH-degrading bacteria from ecologically diverse soils have been studied to identify promising strains for application in bioremediation protocols [12,13]. However, determination of the efficacy of bioremediation via isolation of hydrocarbon-degrading microorganisms from contaminated soils may limit and underestimate the real bioremediation power of indigenous microbial populations due to the presence of unculturable organisms. Recent advances in molecular techniques have extended our ability to profile microbial communities in natural environments using culture-independent methods [14,15]. Cultureindependent approaches are particularly valuable given that more than $99 \%$ of microorganisms cannot be grown in the laboratory ${ }^{[16,17]}$.

Studying microbial communities at the molecular level provides the opportunity to clearly identify microbial community diversity and adaptive responses to environmental contamination ${ }^{[18-20]}$. Community analysis using specific catabolic genes can be used to study microbial community dynamics that could potentially be responsible for PAH degradation ${ }^{[21-25]}$.

Functional genes have been used as biomarkers to monitor the biodegradation potential of natural microbial communities.
However, because of the variation in sources and types of contamination, investigating the distribution of $\mathrm{PAH}$ degrading genes in the environment is still required ${ }^{[26]}$. Functional gene biomarkers used as indicators of PAH degradation include those encoding naphthalene biodegradation in Pseudomonas spp. (nah-genes of the NAH plasmid). The action of dioxygenases on PAHs to incorporate atoms of oxygen at the benzene ring is often the first step in bacterial PAH degradation. The result of this reaction is the formation of cisdihydrodiols, followed by some dihydroxylated intermediates that enter the tricarboxylic acid cycle ${ }^{[27]}$. Naphthalene dioxygenase genes have been found in diverse microbial communities in different contaminated environments. Therefore, microbes carrying NAH plasmids possess the potential to degrade complex substrates like PAHs ${ }^{[28,29]}$. There is no existing reliable method to monitor and detect the diversity of genes involved in PAH degradation. The use of the NAH genes as molecular markers to identify PAH-degrading bacteria is a powerful tool to detect these species' diverse communities ${ }^{[21]}$. Understanding PAH-degrading bacteria in local environments is important; and degradation abilities could be a focal point for future studies and bioremediation applications in the Kingdom of Saudi Arabia. Reports for isolation and characterization of hydrocarbon-degrading microorganisms from the area of the Arabian Gulf and Saudi Arabia are available ${ }^{[30-33]}$. However, monitoring catabolic genes and microbial population changes in hydrocarbon-contaminated soils in Saudi Arabia has not been yet performed and therefore, information regarding the distribution and identity of microbial populations and corresponding catabolic genes in these areas remain unknown. Therefore, the aim of this study was to monitor microbial community structure and population dynamics in response to PAH contamination for future biostimulation protocols and to define certain functional PAH-catabolic genes to be used as bioremediation biomarkers in petroleum hydrocarboncontaminated soils in the city of Almadina Almunawarah, Kingdom of Saudi Arabia, and similar contaminated sites.

\section{Materials and Methods}

\subsection{Site, sampling, and soil analysis}

Soils contaminated with petroleum oil derivatives were collected from areas surrounding local garages, gas stations, lubricating oil car facilities and highway roads in Almadina 
Almunawarah, along with other soil samples from corresponding Yanbu city Table 1. These areas were clearly contaminated with different petroleum products such as crude oil, diesel and lubricant oil. Contaminated soils were sampled from 5-10 cm depth; the soils were very wet and oily and had different colors and texture according to the level of contamination. Collected soil samples were placed into sterile bottles and stored at $4^{\circ} \mathrm{C}$ for future use. Three representative soil samples were collected from each site and then pooled prior to further analysis. Physicochemical characterization of soil samples considered in this study was carried out by AEML (Alamanah Environmental Management Laboratories, Almadinah, KSA, https://medina-lab.com/en/).

\subsection{Establishment of enrichment microcosms}

Bacterial enrichment microcosms were established in $250 \mathrm{ml}$ sterile Duran bottles containing $20 \%(\mathrm{w} / \mathrm{v})$ soil in basal mineral medium ${ }^{\text {[34] }}$ supplemented with $500 \mathrm{mg} / \mathrm{L}$ naphthalene as a model PAH compound. The basal mineral medium used in this study contained (per liter): $\mathrm{K}_{2} \mathrm{HPO}_{4}$, $4.36 \mathrm{~g}$; $\mathrm{NaH}_{2} \mathrm{PO}_{4}, 3.45 \mathrm{~g}$; $\left(\mathrm{NH}_{4}\right)_{2} \mathrm{SO}_{4}, 1.26 \mathrm{~g}$; $\mathrm{MgSO}_{4} .6 \mathrm{H}_{2} \mathrm{O}, 0.91 \mathrm{~g}$; trace salt solution, $1 \mathrm{ml}$. Trace salt solution contained (per $100 \mathrm{ml}$ ): $\mathrm{CaCl}_{2} .2 \mathrm{H}_{2} \mathrm{O}, 4.77 \mathrm{~g}$; $\mathrm{FeSO}_{4} .7 \mathrm{H}_{2} \mathrm{O}, 0.37 \mathrm{~g}$; $\mathrm{CoCl}_{2} .6 \mathrm{H}_{2} \mathrm{O}, 0.37 \mathrm{~g} ; \mathrm{MnCl}_{2}, 0.1 \mathrm{~g} ; \mathrm{Na}_{2} \mathrm{MoO}_{4} .2 \mathrm{H}_{2} \mathrm{O}$, $0.02 \mathrm{~g} ; \mathrm{pH}$ 7. All microcosms were incubated at $30^{\circ} \mathrm{C}$ without shacking for 6 months prior to DNA extraction. Unamended microcosms were prepared and incubated as above. Three replicates' microcosms for each soil were prepared. For further DGGE analysis, only one microcosm was used (most active one).

\subsection{Gas Chromatography (GC) and UV/Vis Spectra}

Gas chromatography was used to monitor the degradation of naphthalene model compound in established microcosms after extraction with methylene chloride. Soil slurry from microcosm was extracted three times with methylene chloride. Extracts were combined in a clean tube and centrifuged at $10,000 \mathrm{rpm}$ for 10 minutes. Samples $(1 \mu \mathrm{l})$ from the supernatant were injected into an Agilent 7890B GC gas chromatographic system equipped with an FID (flame ionization detector). The column was an Agilent J\&W HP-1 (100\% Dimethylpolysiloxane, $60 \mathrm{~m} \times 0.25 \mathrm{~mm}$ id, $0.25 \mu \mathrm{m}$ film thickness) and the carrier gas helium was used at flow rate of $0.8 \mathrm{ml} / \mathrm{min}$. The injector temperature was $250^{\circ} \mathrm{C}$ and the oven temperature was held at $70^{\circ} \mathrm{C}$ for $2 \mathrm{~min}$ then increased to $300^{\circ} \mathrm{C}$ at $20^{\circ} \mathrm{C} / \mathrm{min}$, thereafter, held at $300^{\circ} \mathrm{C}$ for $8 \mathrm{~min}$. UV/Vis absorbance spectra of intermediate compounds were obtained from microcosms after removal of soil debris and cells by centrifugation and filtration through $0.2 \mu \mathrm{m}$ Millipore filters. Filtrates were scanned using UV-visible spectrophotometer (Varian Cary 100, USA). Spectra were recorded between 200 and $600 \mathrm{~nm}$.

\subsection{Extraction and purification of genomic DNA}

Soil samples for DNA extraction were collected from each microcosm and genomic DNA was extracted using the Ultra Clean Soil DNA Purification Kit (Mo Bio Laboratories, Solana Beach, CA, USA) according to the manufacturers' instructions. Extracted DNA was analyzed by electrophoresis on $1 \%(\mathrm{w} / \mathrm{v})$ agarose gels, stained with ethidium bromide and imaged with a UV gel documentation system (Bio-Rad Laboratories Inc., CA, USA).

\subsection{PCR- DGGE}

For Denaturing Gradient Gel Electrophoresis (DGGE) analysis, GC-clamp primers (EUB341FGC) (5'CGCCCGCCGCGCGCGGCGGGCGGGGCGGGGGCACGGGGGGC CTACGGGAGGC AGCAGCAG-3') and (EUB517R) (5' ATTACCGCGGCTGCTGG-3') corresponding to positions 341 and 517 in Escherichia coli were used to amplify the 16S rRNA gene ${ }^{[35]}$. The amplification reaction mixture $(25 \mu \mathrm{l})$ consisted of $0.5 \mathrm{U}$ of Taq DNA polymerase (Invitrogen, USA), $1 \mu$ l of total DNA, $2 \mu$ l of 10x PCR buffer, each primer at a concentration of $0.25 \mu \mathrm{M}$, and a mixture containing each deoxynucleoside triphosphate (dNTPs) at a concentration of $100 \mu \mathrm{M}$. PCR was performed on a 2720 thermal cycler (Applied Biosystems, USA). A touchdown PCR program was implemented as follows: initial denaturation step at $95^{\circ} \mathrm{C}$ for $5 \mathrm{~min} ; 5$ cycles of $94^{\circ} \mathrm{C}$ for 40 $\mathrm{s}$, annealing at $65^{\circ} \mathrm{C}$ for $40 \mathrm{~s}$, and extension at $72^{\circ} \mathrm{C}$ for $40 \mathrm{~s}$; 5 cycles of $94^{\circ} \mathrm{C}$ for $40 \mathrm{~s}$, annealing at $60^{\circ} \mathrm{C}$ for $40 \mathrm{~s}$, and extension at $72^{\circ} \mathrm{C}$ for $40 \mathrm{~s} ; 10$ cycles of $94^{\circ} \mathrm{C}$ for $40 \mathrm{~s}$, annealing at $55^{\circ} \mathrm{C}$ for $40 \mathrm{~s}$, and extension at $72^{\circ} \mathrm{C}$ for $40 \mathrm{~s}$; 10 cycles of $94^{\circ} \mathrm{C}$ for $40 \mathrm{~s}$, annealing at $50^{\circ} \mathrm{C}$ for $40 \mathrm{~s}$, and extension at $72^{\circ} \mathrm{C}$ for $40 \mathrm{~s}$ were performed, followed by a final hold at $72^{\circ} \mathrm{C}$ for $7 \mathrm{~min}$. Amplicons were analyzed by electrophoresis on $1 \%(\mathrm{w} / \mathrm{v})$ agarose gels with size markers (1 Kb DNA Ladder; Invitrogen) and visualized using ethidium bromide. DGGE was performed using the Dcode Mutation Detection System (Bio-Rad Laboratories Ltd., Hertfordshire, UK). PCR products were electrophoresed with $0.5 \times$ TAE buffer (1×TAE buffer is $0.04 \mathrm{M}$ Tris base, $0.02 \mathrm{M}$ sodium acetate, 
and $10 \mathrm{mM}$ EDTA [pH 7.4]) on 8\% acrylamide gel containing 25 to $50 \%$ denaturing gradient of formamide and urea. DGGE was conducted at $60^{\circ} \mathrm{C}$ for $5 \mathrm{~h}$ at $200 \mathrm{~V}$. The gel was stained with SYBR Green I Nucleic acid gel stain (Cambrex Bio Science, Rockland, USA), photographed and analyzed for DGGE band profiles with a UV gel documentation system (Bio-Rad Laboratories, USA).

\subsection{Sequencing of DGGE bands}

Selected DNA bands of the DGGE of total community DNA were cut from the gels with a sterile scalpel and placed in Eppendorf tubes, soaked in TE buffer, boiled for $5 \mathrm{~min}$, and used as template for PCR amplification. PCR of excised DNA fragments was performed using the same bacterial primers as described above but without the GC clamp. Amplification was proved by electrophoresis on $1 \%(\mathrm{w} / \mathrm{v})$ agarose gel. Amplicons were directly sequenced using BigDye terminator cycle sequencing ${ }^{[36]}$ at the Genoscreen sequencing facility (Genoscreen, Lille, France).

\subsection{Sequence and phylogenetic analysis}

$16 \mathrm{~S}$ rDNA sequences were analyzed by Genetyx-Win MFC application software version 4.0. The reference
16S rRNA gene sequences were retrieved from the GenBank database (National Center for Biotechnology Information, National Library of Medicine, USA). Sequences were compared with their closest matches in GenBank with nucleotide-nucleotide BLAST to obtain the nearest phylogenetic neighbors (www.ncbi.nlm.nih.gov/BLAST/). Multi-sequence alignments were performed by ClustalW, and phylogenetic trees were constructed with MEGA 6 software (The Biodesign Institute) (http://www.megasoftware.net/) [37] using evolutionary distance and neighbor-joining method. Bootstrapping was performed on 1,000 replications of the alignments ${ }^{[38]}$.

\subsection{Numerical analysis of DGGE fingerprints}

The DGGE fingerprints were analyzed using Quantity One 1D software (Bio-Rad, UK). Bacterial diversity was assessed using the Shannon-Weaver diversity index $\left(H^{\prime}\right)\left[H^{\prime}=-\Sigma P_{i}\left(\ln P_{i}\right)\right.$, where $\left.P_{i}=n_{i} / N_{i}\right]{ }^{[39]}$. $P_{i}$ is the relative intensity of DNA bands in the fingerprint, $n_{i}$ is densitometrically measured intensity of individual DNA bands, and $N_{i}$ is the total amount of DNA in the fingerprint.

Table 1 Local samples sites and soil contamination type of the collected samples from area around Almadina Almunawarah in the KSA

\begin{tabular}{lllll}
\hline Area & No. & Sampling site & Location (coordinates) & Description \\
\hline Al Meqat & 1 & Omar Ibn Al-Khatab road & $24^{\circ} 25^{\prime} 29^{\prime \prime} \mathrm{N}, 39^{\circ} 32^{\prime} 49^{\prime \prime}$ E & Lubricating oil-contaminated \\
Yanbu road & 2 & Omar Ibn Al-Khatab road & $24^{\circ} 25^{\prime} 23^{\prime \prime} \mathrm{N}, 39^{\circ} 32^{\prime} 43^{\prime \prime} \mathrm{E}$ & Lubricating oil-contaminated \\
& 4 & Yanbu road & $24^{\circ} 21^{\prime} 56^{\prime \prime} \mathrm{N}, 39^{\circ} 31^{\prime} 54^{\prime \prime} \mathrm{E}$ & Petroleum-contaminated soil \\
Al Azizia & 5 & Ylemam Albukhari & $24^{\circ} 21^{\prime} 55^{\prime \prime} \mathrm{N}, 39^{\circ} 312^{\prime} 50^{\prime \prime}$ & Petroleum-contaminated soil \\
Industrial & 6 & Al-Hijrah road & $24^{\circ} 26^{\prime} 56^{\prime \prime} \mathrm{N}, 39^{\circ} 31^{\prime} 51^{\prime \prime}$ E & Tar-contaminated soil \\
area & 7 & Al-Hijrah road & $24^{\circ} 23^{\prime} 28^{\prime \prime} \mathrm{N}, 39^{\circ} 29^{\prime} 56^{\prime \prime}$ E & Diesel oil-contaminated soil \\
& 8 & Al-Hijrah road & $24^{\circ} 23^{\prime} 25^{\prime \prime} \mathrm{N}, 39^{\circ} 29^{\prime} 59^{\prime \prime} \mathrm{E}$ & Diesel oil-contaminated soil \\
& 9 & Al-Hijrah road & $24^{\circ} 23^{\prime} 16^{\prime \prime} \mathrm{N}, 39^{\circ} 30^{\prime} 7^{\prime \prime} \mathrm{E}$ & Lubricating oil-contaminated \\
Yanbu city & 10 & Yanbu & $24^{\circ} 23^{\prime} 5^{\prime \prime} \mathrm{N}, 39^{\circ} 30^{\prime} 15^{\prime \prime} \mathrm{E}$ & Lubricating oil-contaminated \\
& 11 & Yanbu & $23^{\circ} 53^{\prime} 42^{\prime \prime} \mathrm{N}, 38^{\circ} 23^{\prime} 21^{\prime \prime} \mathrm{E}$ & Petroleum-contaminated soil \\
Tabok road & 12 & Tabok road & $23^{\circ} 59^{\prime} 17^{\prime \prime} \mathrm{N}, 38^{\circ} 15^{\prime} 56^{\prime \prime} \mathrm{E}$ & Petroleum-contaminated soil \\
& 13 & Tabok road & $24^{\circ} 30^{\prime} 53^{\prime \prime} \mathrm{N}, 39^{\circ} 31^{\prime} 38^{\prime \prime} \mathrm{E}$ & Tar-contaminated soil \\
& 14 & Tabok road & $24^{\circ} 30^{\prime} 54^{\prime \prime} \mathrm{N}, 39^{\circ} 31^{\prime} 13^{\prime \prime} \mathrm{E}$ & Tar-contaminated soil \\
& 15 & Prince Naif Ibn Abdulaziz & $24^{\circ} 31^{\prime} 1^{\prime \prime} \mathrm{N}, 39^{\circ} 33^{\prime} 59^{\prime \prime} \mathrm{E}$ & Tar-contaminated soil \\
& 16 & Prince Naif Ibn Abdulaziz & $24^{\circ} 31^{\prime} 34^{\prime \prime} \mathrm{N}, 39^{\circ} 35^{\prime} 35^{\prime \prime} \mathrm{E}$ & Tar-contaminated soil \\
& 17 & Prince Naif Ibn Abdulaziz & $24^{\circ} 31^{\prime} 35^{\prime \prime} \mathrm{N}, 39^{\circ} 35^{\prime} 40^{\prime \prime} \mathrm{E}$ & Tar-contaminated soil \\
& & & &
\end{tabular}




\subsection{PCR amplification of aromatic oxygenase genes}

PCR was carried out using oligonucleotide primers specific for key oxygenase genes involved in both aromatic hydrocarbon and PAH biodegradation. Amplifications of catabolic genes were performed in 50 $\mu \mathrm{l}$ total reaction volumes containing: $5 \mu \mathrm{l}$ of $10 \times$ Taq buffer (100 mM Tris-HCl, pH 8), 1.25 mM MgCl, 200 $\mu$ MdNTPs (Invitrogen), $1.2 \mu \mathrm{M}$ of both forward and reverse primers (Invitrogen), $1 \cup$ Taq polymerase (Invitrogen), and about $5 \mathrm{ng}$ of template DNA. PCR was
Performed with the Applied Biosystems 2720 thermal cycler. Primer sequences and PCR parameters used to amplify aromatic oxygenase genes are summarized in Table 2. Amplified genes were electrophoresed on a $1 \%$ $(\mathrm{w} / \mathrm{v})$ agarose gel with size markers (DNA $1 \mathrm{~Kb}$ Ladder; Promega, USA) and visualized using ethidium bromide.

\subsection{Nucleotide sequence accession number}

The $16 \mathrm{~S}$ rDNA sequences identified in this study were deposited in the GenBank database under the accession numbers: AB936786 to AB936796.

Table 2 Primer sequences and PCR parameter used to amplify aromatic oxygenase genes in this study

\begin{tabular}{|c|c|c|c|c|c|c|c|}
\hline Gene & Primers $^{d}$ & Primer sequence $\left(5^{\prime}-3^{\prime}\right)$ & $\begin{array}{l}\text { Nucleotide } \\
\text { length }\end{array}$ & $\begin{array}{c}\text { Fragmen } \\
\text { t size } \\
\text { (bp) }\end{array}$ & Thermal profile ${ }^{\mathrm{e}}$ & Cycles & Reference \\
\hline $\begin{array}{l}\text { Catechol 1,2- } \\
\text { dioxygenase }\end{array}$ & $\begin{array}{l}\mathrm{Cl} 2 \mathrm{Of} \\
\mathrm{Cl} 2 \mathrm{Or}\end{array}$ & $\begin{array}{l}\text { GCCAACGTCGACGTCTGGCA } \\
\text { CGCCTTCAAAGTTGATCTGCGTGGT }\end{array}$ & $\begin{array}{l}20 \\
25\end{array}$ & 282 & $94^{\circ} \mathrm{C}(60 \mathrm{~s}), 56^{\circ} \mathrm{C}(30 \mathrm{~s}), 72^{\circ} \mathrm{C}(30 \mathrm{~s})$ & 35 & [40] \\
\hline $\begin{array}{l}\text { Catechol 2,3- } \\
\text { dioxygenase }\end{array}$ & $\begin{array}{l}\text { C23Of } \\
\text { C23Or }\end{array}$ & $\begin{array}{l}\text { AAGAGGCATGGGGGCGCACCGGTTCGATCA } \\
\text { CCCAGCAAACACCTCGTTGCGGTTGCC }\end{array}$ & $\begin{array}{l}30 \\
26\end{array}$ & 380 & $94^{\circ} \mathrm{C}(60 \mathrm{~s}), 56^{\circ} \mathrm{C}(30 \mathrm{~s}), 72^{\circ} \mathrm{C}(30 \mathrm{~s})$ & 35 & [40] \\
\hline $\begin{array}{l}\text { Catechol 2,3- } \\
\text { dioxygenase- } \\
\mathrm{mt} 2^{\mathrm{a}}\end{array}$ & $\begin{array}{l}x y \mid E f \\
x y \mid E r\end{array}$ & $\begin{array}{l}\text { GTNYTNGGNTTYTAYYTNGCNGAR } \\
\text { NCKRTTNCCNSWNGGRTCRAA }\end{array}$ & $\begin{array}{l}24 \\
21\end{array}$ & 280 & $92^{\circ} \mathrm{C}(40 \mathrm{~s}), 53^{\circ} \mathrm{C}(50 \mathrm{~s}), 72^{\circ} \mathrm{C}(60 \mathrm{~s})$ & 35 & [41] \\
\hline $\begin{array}{l}\text { Toluene } \\
\text { dioxygenase }\end{array}$ & $\begin{array}{l}\text { todC1f } \\
\text { todC1r }\end{array}$ & $\begin{array}{l}\text { CGGGTGGGCTTACGACACCGCCGGCAATCT } \\
\text { TCGAGCCGCGCTCCACGCTACCCAGACGTT }\end{array}$ & $\begin{array}{l}30 \\
30\end{array}$ & 560 & $92^{\circ} \mathrm{C}(40 \mathrm{~s}), 53^{\circ} \mathrm{C}(50 \mathrm{~s}), 72^{\circ} \mathrm{C}(60 \mathrm{~s})$ & 35 & [41] \\
\hline $\begin{array}{l}\text { Naphthalene } \\
\text { dioxygenase }\end{array}$ & $\begin{array}{l}\text { NAHf } \\
\text { NAHr }\end{array}$ & $\begin{array}{l}\text { CAAAA(A/G)CACCTGATT(C/T)ATGG } \\
\text { A(C/T)(A/G)CG(A/G)G(C/G)GACTTCTTTCAA }\end{array}$ & $\begin{array}{l}20 \\
16\end{array}$ & 377 & $95^{\circ} \mathrm{C}(60 \mathrm{~s}), 49^{\circ} \mathrm{C}(60 \mathrm{~s}), 72^{\circ} \mathrm{C}(60 \mathrm{~s})$ & 35 & [42] \\
\hline $\begin{array}{l}\text { Rieske iron } \\
\text { sulfur center }\end{array}$ & $\begin{array}{l}\text { Rieske-f } \\
\text { Rieske-r }\end{array}$ & $\begin{array}{l}\text { AGGGATCCCCANCCRTGRTANSWRCA } \\
\text { GGAATTCTGYMGNCAYMGNGG }\end{array}$ & $\begin{array}{l}26 \\
21\end{array}$ & 78 & $94^{\circ} \mathrm{C}(30 \mathrm{~s}), 48^{\circ} \mathrm{C}(30 \mathrm{~s}), 72^{\circ} \mathrm{C}(30 \mathrm{~s})$ & 35 & [9] \\
\hline
\end{tabular}

${ }^{a}$ catechol 2,3-dioxygenase-mt2 ${ }^{\mathrm{a}}$ encoding gene ( $\left.x y / E\right)$ from $P$. putida $\mathrm{mt}-2$

${ }^{\mathrm{b}}$ Toluene dioxygenase encoding gene (tod $\left.C 1\right)$ from $P$. putida F1

${ }^{c}$ Rieske iron sulfur center common to all PAH dioxygenase enzymes

${ }^{d}$ Forward $(f)$ and reverse $(r)$ primers are indicated

e Thermal profiles for PCR are presented as denaturation, annealing, and extension temperatures.

\section{Results and Discussion}

\subsection{Physicochemical Properties of Soil}

Significant differences in soil properties were found between hydrocarbon-contaminated soils and uncontaminated control soil. Physicochemical characteristics of contaminated soils in comparison with uncontaminated control soil were shown in Table 3. All soils had a $\mathrm{pH}$ ranging from 6.5 to 7 . Four hydrocarbon-contaminated soils (S4, S5, S7 and S8) had higher total dissolved solids (TDS) than the control soil. Contaminated soils also showed higher amounts of nitrate, potassium, calcium, magnesium and chlorine compared with uncontaminated soil. On the other hand, control soil had higher phosphate content than contaminated soils. Total organic carbon ranged from 13 to $21 \%$ in contaminated soils. These results indicate that some basic soil properties might have been changed by different hydrocarbon contamination. Peng et al. ${ }^{[43]}$ demonstrated that total nitrogen, total phosphorus and organic matter were significantly different in oil-contaminated soils exposed to different oil pollution.

\subsection{Enrichment microcosms and initial screening}

Laboratory-scale microcosms were established for enrichment of indigenous bacteria with the capability to degrade PAHs using naphthalene as a model compound. The success of microcosms in enriching microbial populations involved in the biodegradation process can be revealed by increasing turbidity and color change in microcosms. Biodegradation potential for naphthalene in established microcosms was revealed by the reduction in its concentration with time as monitored by GC/FID analysis Fig. 1 A, B. A change in color to yellow has been considered a preliminary evidence for biodegradation via extradiol meta-pathway. Coloration of the medium is usually due to the production of canonical ring cleavage products, hydroxymuconic 


\section{W. S. El-Sayed et al /Egy. J. Pure \& Appl. Sci. 2022; 60(1):1-16}

semialdehyde, during metabolic activity of endogenous bacteria via their oxygenase reactions. It has been reported that extradiol ring cleavage dioxygenases can be easily identified by the presence of such yellow-colored products ${ }^{[44]}$. Hydroxymuconate semialdehyde is a precursor for downstream compounds that fed eventually to the tricarboxylic acid cycle.

Naphthalene as a model compound was used to enrich
PAH-degrading bacteria prior to detection of their catabolic genes. Naphthalene-amended microcosms showed higher turbidity and more intense coloration than unamended microcosms. It is therefore recommended to establish enrichment microcosms prior to PCR detection of catabolic genes as a convenient method for increasing the abundance of the degrading microorganisms and their target genes ${ }^{[45]}$.

Table 3 Physical and chemical characteristics of soils considered in this study

\begin{tabular}{|c|c|c|c|c|c|}
\hline \multirow{2}{*}{ Parameters } & \multicolumn{5}{|c|}{ Soil samples } \\
\hline & Control & S4 & S 5 & S 7 & S 8 \\
\hline Contamination & Uncontaminated & $\begin{array}{l}\text { Petroleum- } \\
\text { contaminated }\end{array}$ & $\begin{array}{c}\text { Tar- } \\
\text { contaminated }\end{array}$ & $\begin{array}{c}\text { Diesel oil- } \\
\text { contaminated }\end{array}$ & $\begin{array}{l}\text { Lubricating oil- } \\
\text { contaminated }\end{array}$ \\
\hline $\mathrm{pH}$ & 6.8 & 6.75 & 6.7 & 6.65 & 6.75 \\
\hline TDS (mg/L) & 425 & 10300 & 10550 & 11350 & 11780 \\
\hline $\mathrm{NO}_{3}(\mathrm{mg} / \mathrm{L})$ & 116 & 947.5 & 883.7 & 911.4 & 961.2 \\
\hline $\mathrm{PO}_{4}(\mathrm{mg} / \mathrm{L})$ & 325 & 235 & 215 & 224 & 238 \\
\hline $\mathrm{K}^{+}(\mathrm{mg} / \mathrm{L})$ & 39 & 325 & 412 & 303 & 338 \\
\hline $\mathrm{Ca}^{2+}(\mathrm{mg} / \mathrm{L})$ & 42.8 & 3120 & 2867 & 3026 & 2637 \\
\hline $\mathrm{Mg}^{2+}(\mathrm{mg} / \mathrm{L})$ & 37.72 & 211.2 & 202.4 & 164.7 & 197.3 \\
\hline $\mathrm{Cl}^{-}(\mathrm{mg} / \mathrm{L})$ & 120 & 5600 & 3200 & 3450 & 4200 \\
\hline Organic carbon (\%) & 5.27 & 13.1 & 17.5 & 21.3 & 16.7 \\
\hline
\end{tabular}

TDS , total dissolved solids

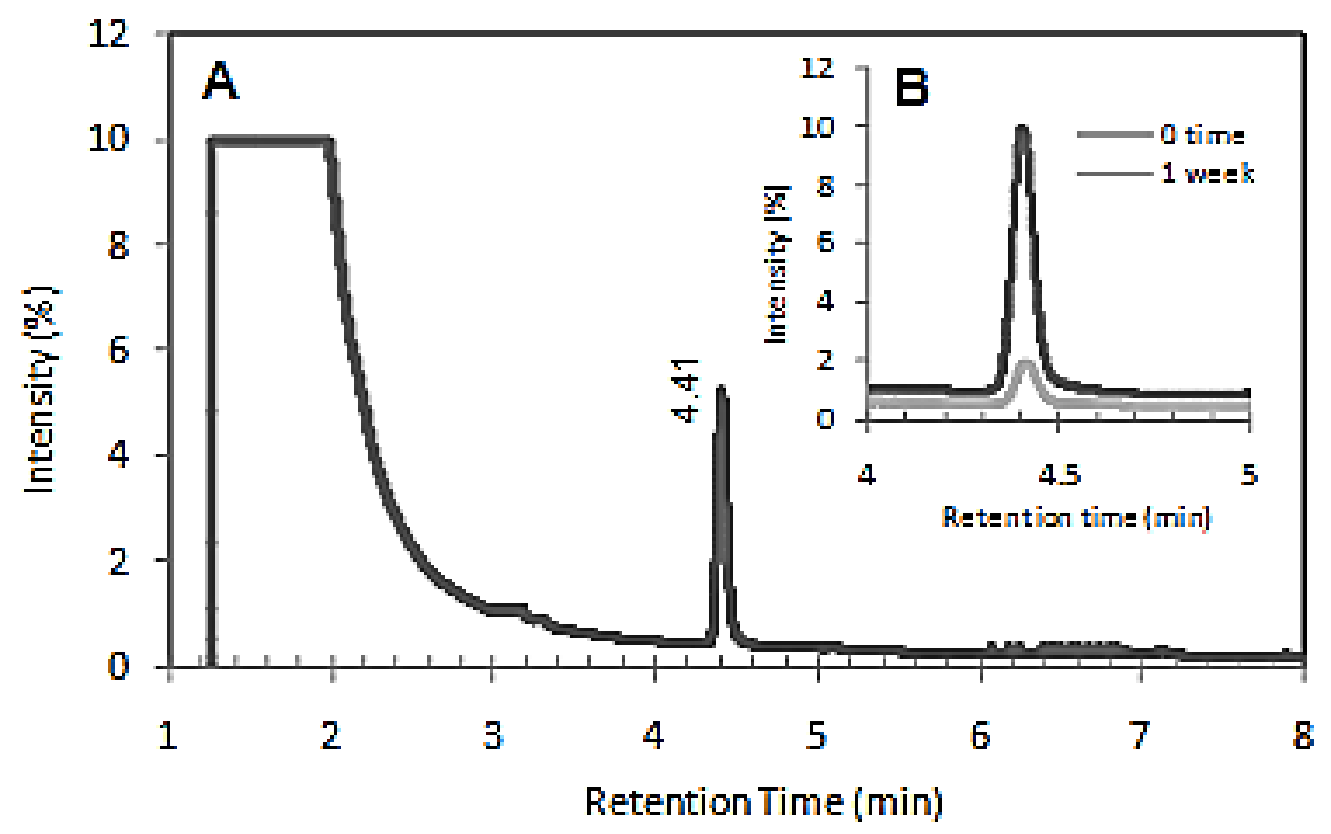

Fig. 1 PAH-biodegradation potential in established microcosm (soil S4). GC/FID chromatogram of authentic naphthalene sample eluted at $4.41 \mathrm{~min}$ (A). GC/FID chromatogram showing the time dependent degradation of naphthalene after one week incubation (B) 


\subsection{Profiling and dynamics of bacterial communities in contaminated soils}

Analysis of $16 \mathrm{~S}$ rRNA genes using DGGE represents a prevailing tool to investigate bacterial populations in native environments and/or laboratory microcosms $[35,46]$. It is also possible to profile microbial community structure by constructing and sequencing the clone libraries of specific catabolic genes ${ }^{[47]}$. The time-dependent change in bacterial community structure for selected unamended soil samples contaminated with different hydrocarbons was analyzed using DGGE of PCR-amplified 16S rRNA genes Fig. $2 A$. Sequenced DGGE bands were identified after BLAST sequence alignments Table 4. Community fingerprints of the non-PAH-treated soil showed that there were no major changes during the first month of incubation. The bacterial profiles of the original unamended soils revealed the general dominance of Pseudomonas spp., $P$. pseudoalcaligenes, $P$. nitroreducens, and $P$. toyotomiensis. In addition to pseudomonads Cellulosimicrobium sp. was also detected in unamended soils. Pseudomonads are known for their distribution in petroleum hydrocarbon contaminated soils due to their biodegradation potential. [18]. However, some soils may have different community structures due to biogeographic characteristics. Peng et al. [43] demonstrated that petroleum-contaminated soils are dominated by Acidobacteria, Actinobacteria, Bacteroidetes, chloroflexi, Planctomycetes, and Proteobacteria.

The community fingerprints observed for contaminated soil samples were different to those obtained from uncontaminated soils. Microbial community structure of one unpolluted soil in Almadina Almunawarah showed a predominance of Photobacterium sp., Allomonas sp., Cellulomonas sp., and uncultured members as major bacterial groups [48]. Uncontaminated arid soils in Almadina Almunawarah were also found to be dominated by members of Pseudomonas, Bacillus, and Enterobacter spp. ${ }^{[49]}$. Therefore, contamination induced a change in the microbial populations, enriching for those with the potential to biodegrade the corresponding contaminant.
Microbial populations in polluted soils or sediments have been studied [50,51]. Degrading populations were frequently affiliated with the genera Sphingomonas, Polaromonas, Burkholderia, Pseudomonas, Mycobacterium, Nocardia, and Rhodococcus ${ }^{[52]}$.

The dynamics of bacterial communities in response to $\mathrm{PAH}$ pollution were analyzed Fig. 2B. The PAH-treated soils showed no drastic changes over time. In contrast, significant changes over time were observed when comparing aged non-PAHtreated soil with $\mathrm{PAH}$-treated soils. Bacterial communities flourished over a relatively long period. PAH-amended soil samples S4, S5 and S7 were dominated by Pseudomonas sp., $P$. pseudoalcaligenes, $P$. nitroreducens, $P$. toyotomiensis and Cellulosimicrobium sp. Soil sample 58 was dominated by uncultured Pseudomonas sp., $P$. mendocina and Stenotrophomonas sp. This suggested that microorganisms could adapt and flourish under the enrichment conditions ${ }^{[53]}$.

Bacterial community structure changes were monitored for soil samples amended with the model PAH naphthalene. After 6 months, some changes in the bacterial populations were observed. The bacterial profile in sample S4 was found to be conserved and almost no changes in the bacterial community structure were observed. A similar situation was found for sample S5, except that one uncultured bacterium appeared over time. Bacterial community structure changes were evident in sample S7 where $P$. pseudoalcaligenes, $P$. nitroreducens, and Pseudomonas sp. disappeared from the community and a new bacterial species, Sphingobacterium sp. Appeared Fig. 2, Table 4. A previous report has shown the successful recovery of previously non-cultivated bacterial strains after the addition of specific growth supplements to the media ${ }^{[54]}$. Naphthalene-amended soil sample S8, which was dominated by uncultured Pseudomonas sp., showed a remarkable change in its bacterial profile with prolonged incubation time. The bacterial community in Sample $\mathrm{S} 8$ after enrichment was dominated by Pseudomonas sp., $P$. pseudoalcaligenes, $P$. nitroreducens, and $P$. toyotomiensis. 
W. S. El-Sayed et al /Egy. J. Pure \& Appl. Sci. 2022; 60(1):1-16

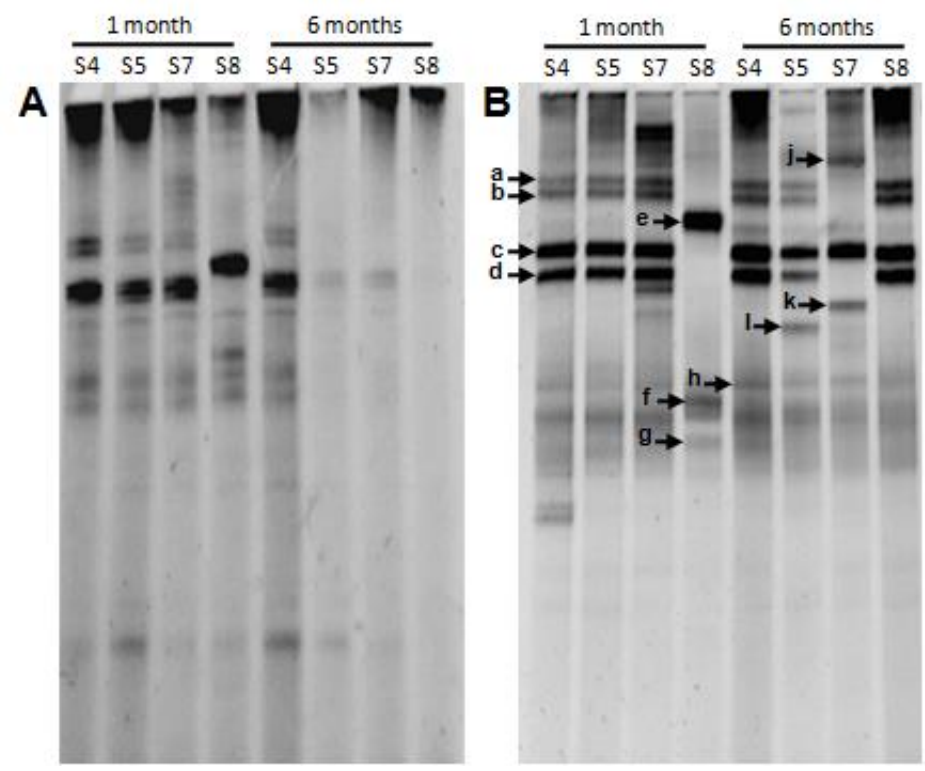

Fig. 2 Denaturing gradient gel electrophoresis of PCR-amplified 16S rRNA genes from unamended (A) and polycyclic aromatic hydrocarbon (PAH)-amended (B) microcosms. The time of sampling (months) is indicated above the lanes

Table 4 Identification of the 16S rDNA sequences from DGGE bands from NCBI database with the highest similarity to each band

\begin{tabular}{|c|c|c|c|c|c|}
\hline \multirow[b]{2}{*}{ Bands } & \multirow[b]{2}{*}{ source } & \multirow[b]{2}{*}{ Accession No. } & \multicolumn{3}{|c|}{ Closest matches } \\
\hline & & & Identity & $\begin{array}{c}\text { Similarity } \\
(\%)\end{array}$ & $\begin{array}{c}\text { Accession } \\
\text { No. }\end{array}$ \\
\hline$A$ & Petroleum-contaminated soil & AB936786 & Pseudomonas pseudoalcaligenes XY4 & 100 & KJ174592.1 \\
\hline B & Petroleum-contaminated soil & AB936787 & Pseudomonas nitroreducens VITWW2 & 100 & KJ146071.1 \\
\hline C & Petroleum-contaminated soil & AB936788 & Pseudomonas toyotomiensis $\mathrm{AO} 0020$ & 100 & KF984313.1 \\
\hline D & Petroleum-contaminated soil & AB936789 & Pseudomonas sp. FSGRN7 & 99 & KJ200412.1 \\
\hline $\mathrm{E}$ & Lubricating oil-contaminated soil & AB936790 & Uncultured Pseudomonas sp. HHG10 & 100 & GU565252.1 \\
\hline $\mathrm{F}$ & Lubricating oil-contaminated soil & AB936791 & Stenotrophomonas sp. SO5.1 & 100 & KC859435.1 \\
\hline G & Lubricating oil-contaminated soil & AB936792 & Pseudomonas mendocina PM2011AH01 & 99 & KJ150296.1 \\
\hline $\mathrm{H}$ & Petroleum-contaminated soil & AB936793 & Cellulosimicrobium sp. H.p10 & 100 & KJ024067.1 \\
\hline 1 & Tar-contaminated soil & AB936794 & Uncultured bacterium clone 7 & 99 & FJ459826.1 \\
\hline J & Diesel oil-contaminated soil & AB936795 & Sphingobacterium sp. TSAR21 & 100 & KC854376.1 \\
\hline K & Diesel oil-contaminated soil & AB936796 & Pseudomonas sp. 9-31 & 100 & HF954515.1 \\
\hline
\end{tabular}

\subsection{Diversity and phylogenetic analysis of DGGE phylotypes}

The Shannon diversity index is an important parameter for estimation of bacterial diversity in environmental samples. The Shannon index $\left(H^{\prime}\right)$ was applied as a compound index to compare timedependent changes in community diversity in unamended and $\mathrm{PAH}$-amended microcosms. In general, species richness is known to be relatively higher in contaminated soils than uncontaminated ones ${ }^{[43]}$.

The bacterial community in unamended microcosms showed a diversity index ranging from 0.99 to 1.9 Fig. $3 \mathrm{~A}, \mathrm{~B}$.
Except for one soil sample (S4), extended incubation time resulted in a gradual decrease in the diversity index (1.7 to 0 ), as revealed by the deterioration of community structure with time. PAH-amended microcosms showed almost no change in diversity with time. The diversity indexes for amended, one monthand six month-incubated microcosms ranged from 2.02 to 0.6 and from 1.7 to 1.27 , respectively. These values suggest that $\mathrm{PAH}$ amendment might result in a conservation of the community structure for those community members involved in the biodegradation process.

Phylogenetic analysis of the detected bacterial species in contaminated soils was performed. The phylogenetic 
tree based on 16S rRNA gene sequences showed the relationship between the detected DGGE phylotypes and closely related representative bacterial members Fig. 4. Phylogenetic studies confirmed the affiliation of DGGE phylotypes a-e and $\mathrm{g}$ to the Pseudomonas spp. group. Phylotypes $i$ and $k$ were affiliated with uncultured

Pseudomonas spp. Phylotype $f$ was clustered with the genera Xanthomonas and Stenotrophomonas. Phylotype $\mathrm{h}$ was clustered with the same phylogenetic branch as Actinobacteria, while phylotype $\mathrm{j}$ was clustered with the Sphingobacterium group.

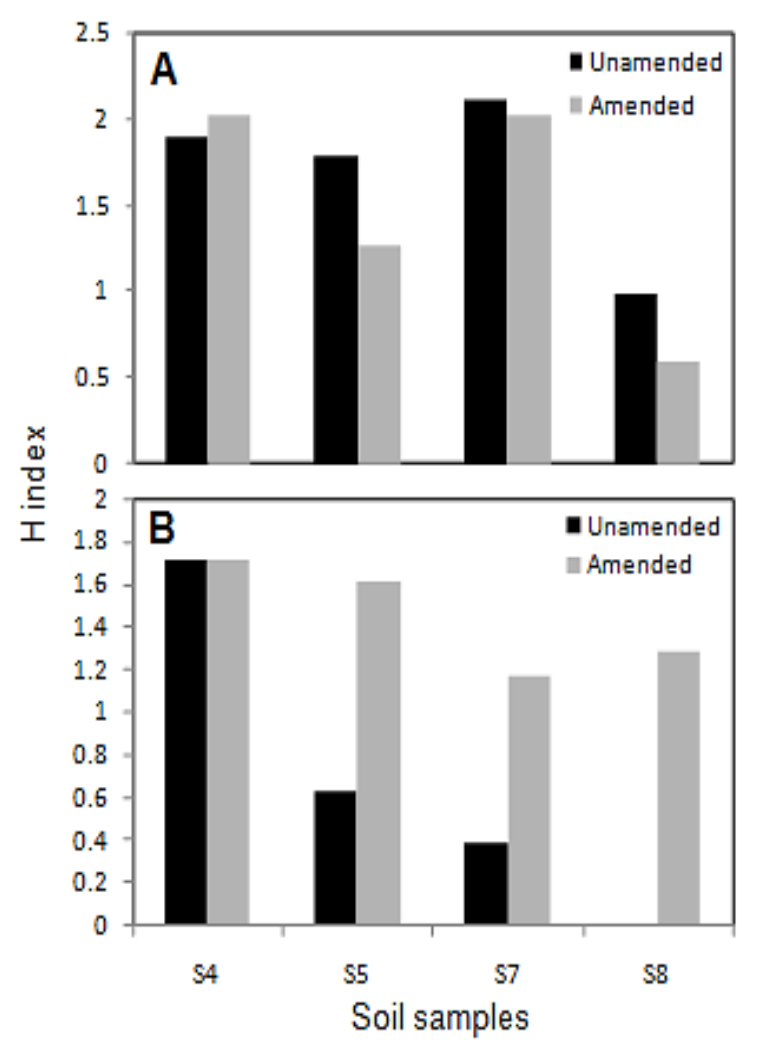

Fig. 3 Shannon diversity index $\left(H^{\prime}\right)$ for PAH-amended and unamended microcosms after one month (A) and six months (B) of incubation

\subsection{Detection of aromatic oxygenase genes}

Adaptation of bacteria to hydrocarbon contamination can be monitored by using specific DNA probes targeting hydrocarbon-catabolic genes. Catabolic genes responsible for the aerobic biodegradation of many hydrocarbons are targeted towards the initial oxidation of hydrocarbons, such as naphthalene dioxygenase or ring cleavage, such as catechol dioxygenase ${ }^{[55]}$. Generally, the enzymes in the upper pathway hydroxylate the aromatic compounds to corresponding diols via the action of a monooxygenase or dioxygenase ${ }^{[56]}$, resulting in the dihydroxy compound. After that, they are subjected to ring cleavage dioxygenases in the lower pathway forming ring-cleavage products.

In this study, PCR primer sets were selected for amplification of major catabolic genes involved in aromatic metabolism including different aromatic oxygenases. The primers were selected to cover key steps in the upper and lower aromatic pathways. To cover up the upper pathway, naphthalene dioxygenase (NAH), toluene dioxygenase (todC1), and Rieske-type clusters encoding fragments common to most dioxygenases were selected. Oxygenase genes have been identified and isolated from a number of polluted soils ${ }^{[57]}$. Catechol 1,2dioxygenase (C12O) and catechol 2,3-dioxygenase (C230, xylE) were selected to cover the lower pathway. PCR results showed that the $\mathrm{C} 230$ primer set allowed amplification of extradiol ring cleavage dioxygenase genes from all soils amended with naphthalene Fig. 5. In unamended soils, C23O primers were able to amplify dioxygenase gene fragments from some soil samples but not all. Likewise, the NAH primer set amplified naphthalene dioxygenase gene fragments from some amended soils but not all. Naphthalene degradation genes, including nah, pah, ndo and dox operons, are highly conserved in some soil pesudomoads ${ }^{[58]}$. Although the NAH gene was regarded as one of the main marker genes used to detect bacteria involved in PAH biodegradation, it was not possible to detect it in unamended soils most properly because they are under the detection limits. When stimulated, it could be detected easily. Moreover, the xylE gene, encoding catechol 2,3-dioxygenase of toluene and methyl benzene derivatives, could not be detected in most of the soils in this study, especially when naphthalene was added as sole carbon source. 
W. S. El-Sayed et al /Egy. J. Pure \& Appl. Sci. 2022; 60(1):1-16

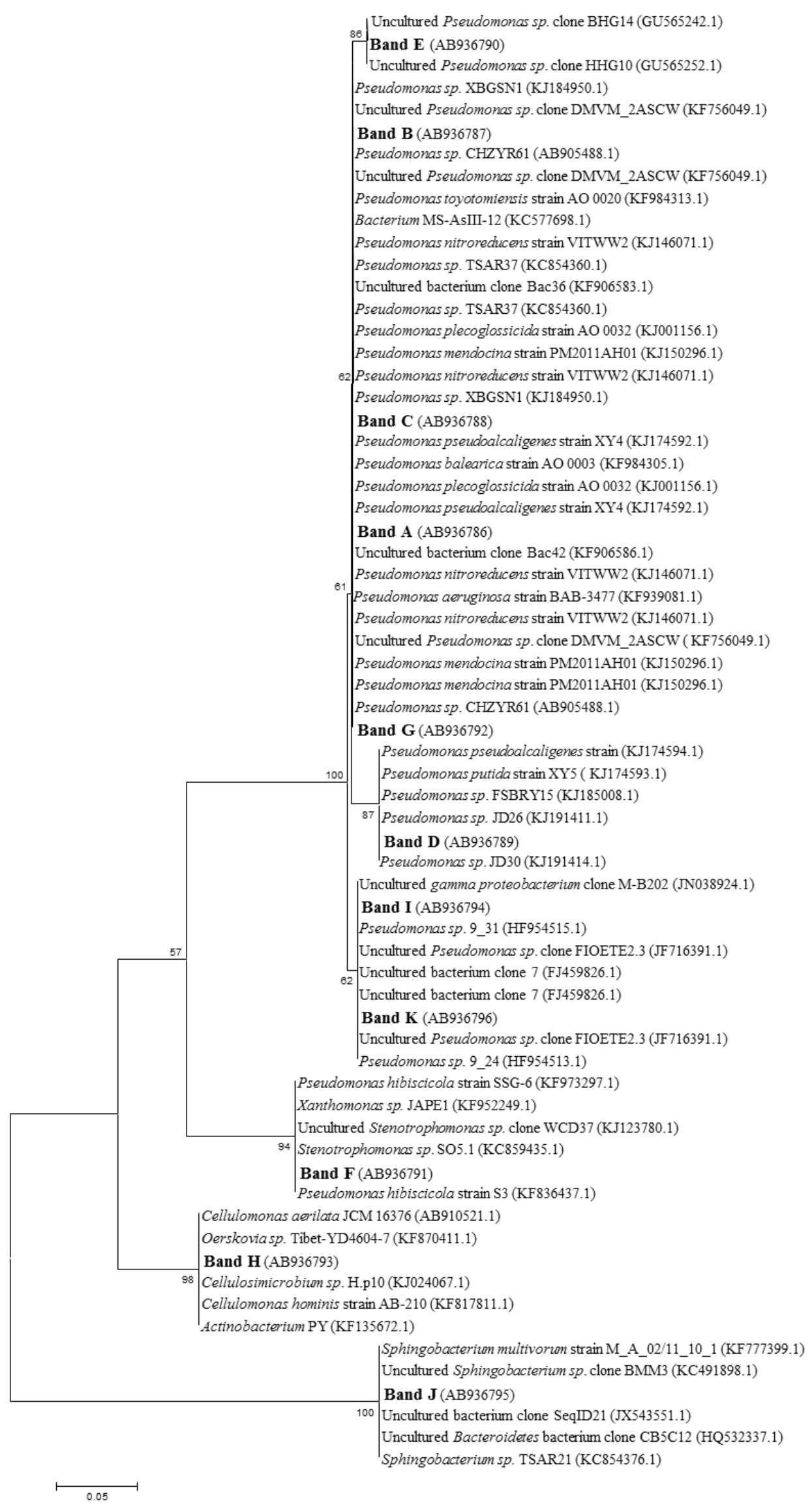

Fig. 4 Neighbor-joining phylogenetic tree showing the relationship between detected bacteria from contaminated soil samples and closest matches from GenBank data base. The bar represents 0.05 substitutions per site. The phylogenetic tree was generated using MEGA 6 software, bootstrap values $(n=1000)$ are displayed 


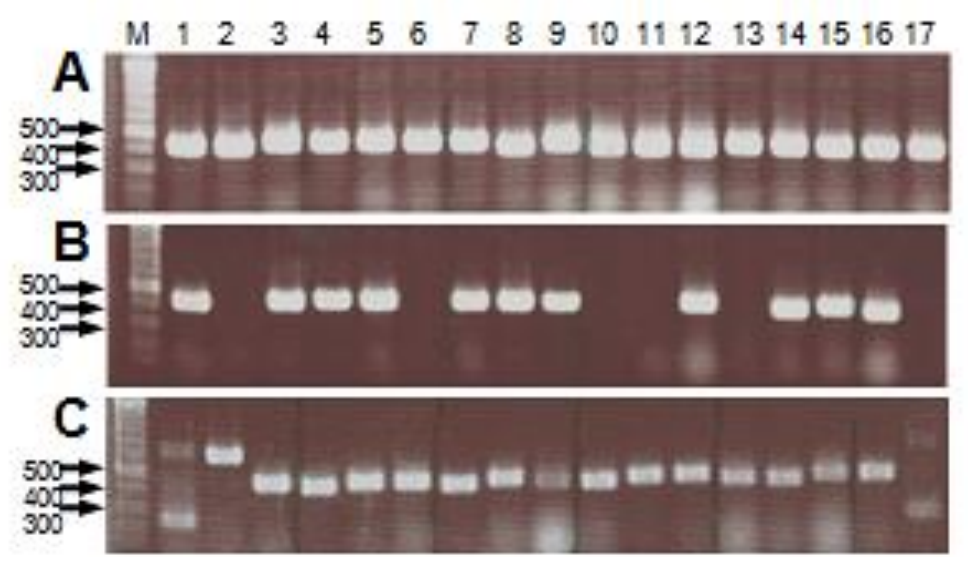

Fig. 5 PCR amplification of catabolic genes from amended and unamended microcosms. PCR amplification of DNA fragments corresponding to naphthalene dioxygenase directly from unamended microcosm (A); PCR amplification of DNA fragments corresponding to catechol 2,3-dioxygenase (C230) directly from unamended microcosm (B); and after enrichment with naphthalene (C). Lane $M$ represents molecular weight size marker (DNA $1 \mathrm{~Kb}$ Ladder). Non-specific amplifications were considered negative

\subsection{Evaluation of catabolic genes as markers for PAH biodegradation}

Degradation of complex PAH mixtures is naturally mediated by extensive microbial diversity. Molecular markers can be used to profile the degradative activities of microbial communities. Kappell et al. [15] found that functional genes involved in oil and PAHs degradation were abundant in oil-contaminated sand beach, suggesting that biodegradation was ongoing. Naturally occurring bacterial isolates capable of catabolizing PAHs have received considerable attention because of the environmental persistence and toxicity of PAHs. Microbial populations are dynamic and are therefore not easily characterized. It has been reported that functional genes could be useful not only for detecting certain microbes but also for monitoring changes in community structure of contaminant-degrading bacteria in microcosms [59]. The accuracy and assessment of this step is very important for successful biodegradation. Characterization of aromatic catabolic pathways has led to a selection of catabolic genes as candidate markers to reveal the biodegradation potential of contaminated environments. The amplification potential and dominance of catabolic genes in various contaminated soils was shown in Fig. 6. The PCR amplification potential for catechol dioxygenase [60] and naphthalene dioxygenase ${ }^{[55]}$ catabolic genes in the studied contaminated soils was evaluated. The C230 primer set was able to amplify specific DNA fragments of $380 \mathrm{bp}$ from all the contaminated soils.
These primers were designed from conserved regions of the C230 gene from different species of hydrocarbon-degrading bacteria ${ }^{[40]}$. Detection of C23O genes in test soils revealed the over distribution of corresponding extradiol ring cleavage dioxygenases in the studied petroleum-contaminated soils. The other gene studied was the $x y / E$ gene, which encodes catechol 2,3-dioxygenase. Specific primer sets for the $x y / E$ gene were not able to amplify this gene from the soils in this study. This could be explained by the absence of appropriate substrates (toluene, benzene, or methyl benzene derivatives), especially in the enrichment cultures. Therefore, C230 was superior to $x y I E$ for detecting PAH catabolic potentials. However, negative PCR amplification of $\mathrm{C} 12 \mathrm{O}$ indicated the limitation or absence of intradiol ring cleavage dioxygenases in the studied contaminated soils. Genes extensively used as indicators of PAH degradation are those encoding naphthalene biodegradation in Pseudomonas spp. (nah-genes of the NAH plasmid). Naphthalene dioxygenase genes have been detected in a range of environments especially in polluted sites [28,29]. Abundance and diversity of naphthalene dioxygenase genes in oil-contaminated soils has been studied in some oil fields like the Shengli oil field, China [26]. NAH primers targeting naphthalene dioxygenase were successful in amplifying the corresponding DNA fragments of the expected size in enrichment cultures amended with naphthalene. In contrast, no NAH PCR product was obtained from unamended contaminated soils. 
Results indicated that the NAH gene was useful as a marker gene. Enrichment microcosms should be established prior to PCR detection, as the inclusion of naphthalene in enrichment microcosms would lead to an increase in the corresponding naphthalene degraders. It has also been shown that in some PAH-contaminated soils and sediments, expression of naphthalene catabolic genes was positively correlated with naphthalene concentrations ${ }^{[45]}$. Rieske-type primers amplified target fragments in some amended contaminated soil samples. XylE and todC were not appropriate for use as marker genes to monitor $\mathrm{PAH}$ biodegradation in this study.

These results suggested that $\mathrm{C} 230$ and $\mathrm{NAH}$ primers could be used as a detection system for $\mathrm{PAH}$ biodegradation in petroleum-contaminated soils. Archetypical naphthalene and catechol dioxygenase genes were found in two Pseudomonas strains isolated from contaminated sediments, suggesting biodegradation potential in these sediments ${ }^{[7]}$. It was also concluded that the biodegradation potential of PAHs in contaminated soils occurs through dioxygenases and further metabolism via extradiol meta pathways revealed by the accumulation of the canonical, yellowcolored intermediates in established microcosms characteristic for such type of activity.

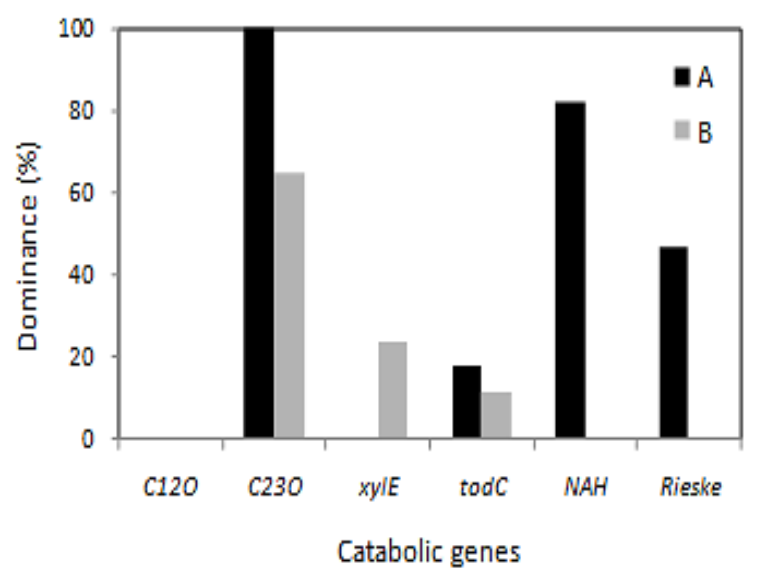

Fig. 6 Evaluation of catabolic genes as markers for $\mathrm{PAH}$ biodegradation revealed by PCR detection of major catabolic genes in contaminated soils

\section{Conclusion}

Saudi Arabia has the largest proven crude oil reserves in the world and therefore incidence of oil pollution is much frequent. Bioremediation is one of the main strategies for treatment of various forms of oil pollution problems in Arabian Gulf area in general and KSA in particular. The present study demonstrated that the soil investigated at Almadina Almunawarah, Yanbu city, KSA harbored hydrocarbon-degrading bacterial populations that could be biostimulated to achieve effective bioremediation of petroleum hydrocarbon contamination. Community fingerprints of contaminated soils in Almadina Almunawarah, Yanbu city, showed the predominance of a variety of Pseudomonas spp. along with Cellulosimicrobium sp. and Stenotrophomonas sp. Soils amended with PAHs showed a conservation and selection of specific microbial communities mainly involved in biodegradation processes. Naphthaleneamendment generally resulted in the predominance of several pseudomonads such as Pseudomonas sp.,

$P$. pseudoalcaligenes, $P$. nitroreducens, and $P$. toyotomiensis and recovery of novel species like Sphingobacterium sp. Hydrocarbon-contaminated soils in Almadina Almunawarah, Yanbu city harbored the archetypical naphthalene dioxygenase (NAH) and catechol 2,3-dioxygenase (C230) encoding genes. These catabolic functional genes were proved to be useful markers for monitoring $\mathrm{PAH}$ biodegradation at petroleum-contaminated.

\section{Conflict of Interest Statement}

The authors declare that the research was conducted in the absence of any commercial or financial relationships that could be construed as a potential conflict of interest.

\section{Acknowledgments}

We gratefully acknowledge the funding of this work by King Abdulaziz City for Science and Technology. We thank AEML (Alamanah Environmental Management Laboratories, Almadinah, KSA) for soil physicochemical analysis. 


\section{References}

1. Mulligan, C., Yong, R. and Gibbs, B. (2001). Surfactant-enhanced remediation of contaminated soil: a review. Eng. Geol., 60: $371-380$.

2. Bamforth, S. M. and Singleton, I. (2005). Bioremediation of polycyclic aromatic hydrocarbons: current knowledge and future directions. J. Chem. Technol. Biotechnol., 80: 723 - 736.

3. Zhou, Q. and Hua, T. (2004). Bioremediation: A review of applications and problems to be resolved. Prog. Nat. Sci., 14: 937 - 944.

4. Maliszewska-Kordybach, B. (1999). Sources, concentrations, fate and effects of polycyclic aromatic hydrocarbons (PAHs) in the environment. Part A: PAHs in air. Polish J. Environ. Stud., 8: $131-136$.

5. Mrozik, A., Piotrowska-Seget, Z. and Labuzek, S. (2003). Bacterial degradation and bioremediation of polycyclic aromatic hydrocarbons. P. Environ. Stud., 12: 15 26.

6. Lu, X.Y., Zhang, T. and Fang, H. H. P. (2011). Bacteria-mediated PAH degradation in soil and sediment. Appl. Microbiol. Biotechnol., 89: 1357 - 1371.

7. Isaac, P., Sánchez, L. A., Bourguignon, N., Cabral, M. E. and Ferrero, M. A. (2013). Indigenous PAH-degrading bacteria from oil-polluted sediments in Caleta Cordova, Patagonia Argentina. Inter. Biodeter. Biodeg., 82: 207 - 214.

8. Andreoni, V., Cavalca, L., Rao, M. A., Nocerino, G., Bernasconi, S., Dell'Amico, E., Colombo, M. and Gianfreda, L. (2004). Bacterial communities and enzyme activities of PAHs polluted soils. Chemosphere, 57: $401-412$.

9. Ní Chadhain, S. M., Norman, R. S., Pesce, K. V., Kukor, J. J., and Zylstra, G. J. (2006). Microbial dioxygenase gene population shifts during polycyclic aromatic hydrocarbon biodegradation. Appl. Environ. Microbiol., 72: $4078-4087$.
10. Launen, L. A., Dutta, J., Turpeinen, R., Eastep, M. E., Dorn, R., Buggs, V. H., Leonard, J. W. and Häggblom, M. M. (2008). Characterization of the indigenous PAH-degrading bacteria of Spartina dominated salt marshes in the New York/New Jersey Harbor. Biodegradation, 19: $347-363$.

11. Llado, S., Covino, S., Solanas, A. M., Petruccioli, M., D'annibale, A. and Vinas, M. (2015). Pyrosequencing reveals the effect of mobilizing agents and lignocellulosic substrate amendment on microbial community composition in a real industrial PAH-polluted soil. J. Hazard. Mater., 283: 35 - 43.

12. Mueller, J. G., Devereux, R., Santavy, D. L., Lantz, S. E., Willis, S. G. and Pritchard, P. H. (1997). Phylogenetic and physiological comparisons of PAH-degrading bacteria from geographically diverse soils. Antonie Van Leeuwenhoek, 71: $329-343$.

13. Yuan, H., Yao, J., Masakorala, K., Wang, F., Cai, M. and Yu, C. (2014). Isolation and characterization of a newly isolated pyrenedegrading Acinetobacter strain USTB-X. Environ. Sci. Pollut. Res., 21: 2724 - 2732.

14. Lamendella, R., Strutt, S., Borglin, S., Chakraborty, R., Tas, N., Mason, O. U., Hultman, J., Prestat, E., Hazen, T. C. and Jansson, J. K. (2014). Assessment of the Deepwater Horizon oil spill impact on Gulf coast microbial communities. Front. Microbiol., 5: 130.

15. Kappell, A. D., Wei, Y., Newton, R. J., Van Nostrand, J. D., Zhou, J., Mclellan, S. L. and Hristova, K. R. (2014). The polycyclic aromatic hydrocarbon degradation potential of Gulf of Mexico native coastal microbial communities after the Deepwater Horizon oil spill. Front. Microbiol., 5: 205.

16. Amann, R. I., Ludwig, W. and Schleifer, K. H. (1995). Phylogenetic identification and in situ detection of individual microbial cells without cultivation. Microbiological Rev., 59(1): $143-69$. 
17. Head, I., Saunders, J. and Pickup, R. (1998). Microbial Evolution, Diversity, and Ecology: A Decade of Ribosomal RNA Analysis of Uncultivated Microorganisms. Microbial Ecology, 35(1): 1- 21.

18. Kostka, J. E., Prakash, O., Overholt, W. A., Green, S. J., Freyer, G., Canion, A., Delgardio, J., Norton, N., Hazen, T. C. and Huettel, M. (2011). Hydrocarbon-degrading bacteria and the bacterial community response in Gulf of Mexico beach sands impacted by the deepwater horizon oil spill. Appl. Environ. Microbiol., 77(22): 7962 7974.

19. Obayori, S. O. and Salam, L. B. (2010). Degradation of polycyclic aromatic hydrocarbons: role of plasmids. Sci. Res. Ess., 5: 4093 - 4106.

20. Nogales, B. M. P., Lanfranconi, J. M., PinaVillalonga, and Bosch, R. (2011). Anthropogenic perturbations in marine microbial communities. FEMS Microbiol. Rev., 35: 275 - 298.

21. Doyle, E., Muckian, L., Hickey, A. M. and Clipson, N. (2008). Microbial PAH degradation. Adv. Appl. Microbiol., 65: 27 66.

22. Kloos, K., Munch, J. C. and Schloter, M. (2006). A new method for the detection of alkane monooxygenase homologous genes (alkB) in soils based on PCR-hybridization. J Microbiol Methods., 66: 486 - 496.

23. Sei, K., Sugimoto, Y., Mori, K., Maki, H. and Kohno, T. (2006). Monitoring of alkane degrading bacteria in a sea-water microcosm during crude oil degradation by polymerase chain reaction based on alkane-catabolic genes. J. Microbiol. Meth., 64(2): $250-265$.

24. Bengtsson, G., Törneman, N., De Lipthay, J. R. and Sørensen, S. J. (2013). Microbial Diversity and PAH Catabolic Genes Tracking Spatial Heterogeneity of PAH Concentrations. Microb. Ecol., 65(1): 91 -100.

25. Fuentes, S., Méndez, V., Aguila, P. and Seeger, M. (2014). Bioremediation of petroleum hydrocarbons: catabolic genes, microbial communities, and applications. App. Microbiol. Biotechnol., 98(11): 4781 4794.
26. Yang, Y., Wang, J., Liao, J., Xie, S. and Huang, Y. (2014). Distribution of naphthalene dioxygenase genes in crude oil-contaminated soils. Microb. Ecol., 68(4): $785-793$.

27. Kanaly, R. A. and Harayama, S. (2000). Biodegradation of High-Molecular-Weight Polycyclic Aromatic Hydrocarbons by Bacteria. J. Bacteriol., 182(8): 2059 - 2067.

28. Laurie, A. D. and Lloyd-Jones, G. (2000). Quantification of phnAc and nahAc in contaminated new zealand soils by competitive PCR. Appl. Environ. Microbiol., 66: $1814-1817$.

29. Tuomi, P. M., Salminen, J. M. and Jørgensen, K. S. (2004). The abundance of nahAc genes correlates with the 14Cnaphthalene mineralization potential in petroleum hydrocarbon-contaminated oxic soil layers. FEMS Microbiol. Ecol., 51: 99 107.

30. Al-Mailem, D. M., Sorkhoh, N. A., AlAwadhi, H., Eliyas, M. and Radwan, S. S. (2010). Biodegradation of crude oil and pure hydrocarbons by extreme halophilic archaea from hypersaline coasts of the Arabian Gulf. Extremo., 14: $321-328$.

31. Bonfá, M. R., Grossman, M. J., Mellado, E. and Durrant, L. R. (2011). Biodegradation of aromatic hydrocarbons by Haloarchaea and their use for the reduction of the chemical oxygen demand of hypersaline petroleum produced water. Chemosphere., 84(11): 1671 - 1676

32. El-Tarrs, A. E., Shahaby, A. F., Awad, N. S., Bahobial, A. S. and El abib, O. A. (2012). In vitro screening for oil degrading bacteria and evaluation of their biodegradation potential for hydrocarbon. Afr. J. Microbiol. Res., 6(49): 7534 - 7544.

33. Ibrahim, M. M., Al-Turki, A., Al-Sewedi, D., Arif, I. A. and El-Gaaly, G. A. (2015). Molecular application for identification of polycyclic aromatic hydrocarbons degrading bacteria (PAHD) species isolated from oil polluted soil in Dammam, Saud Arabia. Saud. J. Biol. Sci., 22(5): $651-655$. 
34. Farrell, A. and Quilty, B. (1999). Degradation of mono-chlorophenols by a mixed microbial community via a metacleavage pathway. Biodegradation, 10: 353 -362 .

35. Muyzer, G. and Smalla, K. (1998). Application of denaturing gradient gel electrophoresis (DGGE) and temperature gradient gel electrophoresis (TGGE) in microbial ecology. Antonie Van Leeuwenhoek, 73(1): $127-141$.

36. Sanger, F., Nicklen, S. and Coulson, A. R. (1977). DNA sequencing with chaintermination inhibitors. Proc. Natl. Acad. Sci. USA, 74: 5463 - 5467.

37. Tamura, K., Dudley, J., Nei, M. and Kumar, S. (2007). MEGA4: Molecular Evolutionary Genetics Analysis (MEGA) software version 4.0. Molecular Biology and Evolution, 24(8): $1596-1599$.

38. Saitou, N. and Nei, M. (1987). The neighborjoining method: a new method for reconstructing phylogenetic trees. Mol. Biol. Evol., 4(4): $406-425$.

39. Ping, L., Yanxin, W., Yanhong, W., Kun, L. and Lei, T. (2010). Bacterial community structure and diversity during establishment of an anaerobic bioreactor to treat swine wastewater. Water Sci. Technol., 62: 243 - 252.

40. Sei, K., Asano, K., Tateishi, N., Mori, K., Ike, M. and Fujita, M. (1999). Design of PCR primers and gene probes for the general detection of bacterial populations capable of degrading aromatic compounds via catechol cleavage pathways. J. Biosci. Bioeng., 88: 542 -550.

41. Cavalca, L., Di Gennaro, P., Colombo, M., Andreoni, V., Bernasconi, S., Ronco, I. and Bestetti, G. (2000). Distribution of catabolic pathways in some hydrocarbon-degrading bacteria from a subsurface polluted soil. Res. Microbiol., 151: $877-887$.

42. Baldwin, B. R., Nakatsu, C. H. and Nies, L. (2003). Detection and enumeration of aromatic oxygenase genes by multiplex and real-time PCR. Appl. Environ. Microbiol., 69: $3350-3358$.
43. Peng, M., Zi, X. and Wang, Q. (2015). Bacterial Community Diversity of Oil-Contaminated Soils Assessed by High Throughput Sequencing of $16 S$ rRNA Genes. Int. J. Environ. Res., 12: 12002 - 12015.

44. Eltis, L. D. and Bolin, J.T. (1996). Evolutionary relationships among extradiol dioxygenases. J. Bacteriol., 178: 5930 - 5937.

45. Cébron, A., Norini, M. P., Beguiristain, T. and Leyval, C. (2008). Real-Time PCR quantification of PAH-ring hydroxylating dioxygenase (PAHRHD alpha) genes from Gram positive and Gram negative bacteria in soil and sediment samples. J. Microbiol. Methods, 73: 148 - 159.

46. Brito, E., Guyoneaud, R., Goni-Urriza, M., Ranchou-Peyruse, A., Verbaere, A., Crapez, M. and Duran, R. (2006). Characterization of hydrocarbon clastic bacterial communities from mangrove sediments in Guanabara Bay, Brazil. Res. Microbiol., 157(8): 752 - 762.

47. Ciric, L., Griffiths, R. I., Philp, J. C. and Whiteley, A. S. (2010). Field scale molecular analysis for the monitoring of bacterial community structures during on-site diesel bioremediation. Bioresource Technology, 101(14): $5235-5241$.

48. El-Sayed, W. S. and Ibrahim, R. A. (2015). Diversity and Phylogenetic Analysis of Endosymbiotic Bacteria of the Date Palm Root Borer Oryctes agamemnon (Coleoptera: Scarabaeidae). BMC Microbiol., 15(88): 1 - 10.

49. El-Sayed, W. S., Akhkha, A., El-Naggar, M. and Elbadry, M. (2014). In vitro Antagonistic Activity, Plant Growth Promoting Traits and Phylogenetic Affiliation of Rhizobacteria Associated with Wild Plants Grown in Arid Soil. Front. Microbiol., 5(651): 1 - 11.

50. Gomes, R., Levison, H. F., Tsiganis, K. and Morbidelli, A. (2005). Origin of the cataclysmic Late Heavy Bombardment period of the terrestrial planets. Nature, 435(7041): 466-469.

51. Flocco, C. G., Gomes, N. C. M., Mac Cormack, W. and Smalla, K. (2009). Occurrence and diversity of naphthalene dioxygenase genes in soil microbial communities from the Maritime Antarctic. Environ. Microbiol., 11(3): $700-714$. 
52. Ding, G. C., Heuer, H. and Smalla, K. (2012). Dynamics of bacterial communities in two unpolluted soils after spiking with phenanthrene: soil type specific and common responders. Front. Microbiol., 3: 290.

53. Zhang, X. Z., Xie, J. J. and Sun, F. L. (2014). Effects of three polycyclic aromatic hydrocarbons on sediment bacterial community. Curr. Microbiol., 68(6): 756 762.

54. Gallego, S., Vila, J., Tauler, M., Nieto, J. M., Breugelmans, P., Springael, D. and Grifoll, M. (2014). Community structure and $\mathrm{PAH}$ ring-hydroxylating dioxygenase genes of a marine pyrene-degrading microbial consortium. Biodegradation, 25(4): $543-556$.

55. Park, J. W. and Crowley, D. E. (2006). Dynamic changes in nahAc gene copy numbers during degradation of naphthalene in PAH-contaminated soils. Appl. Microbiol. Biotechnol., 72: 1322 1329.

56. Gibson, D. T. and Parales, R. E. (2000). Aromatic hydrocarbon dioxygenases in environmental biotechnology. Curr. Opin. Biotechnol., 11: 236 - 243.
57. Nagayama, H., Sugawara, T., Endo, R., Ono, A., Kato, H., Ohtsubo, Y., Nagata, Y. and Tsuda, M. (2015). Isolation of oxygenase genes for indigo-forming activity from an artificially polluted soil metagenome by functional screening using Pseudomonas putida strains as hosts. Appl. Microbiol. Biotechnol., 99(10): 4453 - 4470.

58. Yang, Y., Chen, R. F. and Shiaris, M. P. (1994). Metabolism of naphthalene, fluorene, and phenanthrene: preliminary characterization of a cloned gene cluster from Pseudomonas putida NCIB 9816. J. Bacteriol., 176(8): 2158 - 2164.

59. Ringelberg, D. B., Talley, J. W., Perkins, E. J., Tucker, S. G., Luthy, R. G., Bouwer, E. J., and Fredrickson, H. L. (2001). Succession of phenotypic, genotypic, and metabolic community characteristics during in vitro bioslurry treatment of polycyclic aromatic hydrocarbon-contaminated sediments. Appl. Environ. Microbiol., 67: 1542 - 1550.

60. Mesarch, M. B., Nakatsu, C. H. and Nies, L. (2004). Bench-scale and field-scale evaluation of catechol 2,3-dioxygenase specific primers for monitoring BTX bioremediation. Water Res., 38: 1281 1288. 